\title{
Photoreactive DNA as a tool for studying topography of nucleotide excision repair complex
}

\author{
N. I. Rechkunova, Y. S. Krasikova, E. A. Maltseva, O. I. Lavrik \\ Novosibirsk Institute of Chemical Biology and Fundamental Medicine, Siberian Branch of the Russian Academy of Sciences \\ 8, Akademika Lavrentieva Ave., Novosibirsk, Russian Federation, 630090 \\ nadyarec@niboch.nsc.ru
}

\begin{abstract}
Nucleotide excision repair (NER) is one of the major DNA repair pathways in eukaryotic cells preventing genetic abnormalities caused by DNA damage. NER removes a wide set of structurally diverse lesions such as pyrimidine dimers arising upon UV irradiation and bulky chemical adducts arising upon exposure to environmental carcinogens or chemotherapeutic drugs. In view of the extraordinarily broad substrate specificity of NER, it is of interest to understand how a certain set of proteins recognizes various DNA lesions in the context of a large excess of intact DNA. This review focuses on contribution of photoaffinity labeling technique in the study of DNA damage recognition and following stages resulting in preincision complex assembly, the key and still most unclear steps of NER.
\end{abstract}

Keywords: nucleotide excision repair, damage recognition, preincision complex, photoreactive DNA.

Endogenous reactive metabolites and exogenous factors lead to various damages in cellular DNA. The genetic stability of organisms is achieved by a broad spectrum of repair mechanisms (for review, see [1]), among them nucleotide excision repair (NER) plays an important role. This process removes a wide range of lesions distorting the double helix such as pyrimidine dimers arising upon UV irradiation and bulky chemical adducts with environmental cancerogenic compounds or chemotherapeutic drugs [2]. NER defects lead to severe diseases including some forms of cancer. NER involves more than 30 polypeptides [2]. There are two pathways of NER: global genome repair (GG-NER), removing lesions in the whole genome DNA, and transcription coupled repair (TC-NER) operating with the transcribed DNA strand. TC-NER is associated with the functioning of RNA-polymerase II; its arrest at the damage site is a signal for the assembly of repair protein complex $[3,4]$.

The overall molecular mechanism of GG-NER is generally understood. The removal of a lesion is a sequential process and includes the following steps: damage

(C) Institute of Molecular Biology and Genetics, NAS of Ukraine, 2012 recognition, DNA unwinding around the damage (formation of open complex), excision of damaged fragment, and gap filling (DNA resynthesis). The GG-NER process has been reconstructed in an in vitro system [5]. It was shown that only six core repair factors (XPCRad23B, XPA, RPA, TFIIH, XPG, and ERCC1-XPF) are necessary and sufficient for repairing most lesions in vitro [6]. XPC-Rad23B is now considered as a primary damage sensor in GG-NER [7, 8]. However, the subsequent assembly of NER factors on the damaged DNA, the composition and the lifetime of intermediate structures, and the precise mechanism of the reaction are not yet fully understood.

NER is a multistep process that is carried out through the formation of unstable intermediate complexes enabled by the DNA-protein and protein-protein interactions. One of the approaches to reveal unstable interactions and define the structure of intermediate complexes is the affinity labeling using photoreactive DNA structures mimicking intermediates of different stages of the repair process [9-12]. This method allows studying the architecture of DNA-protein complexes appearing during NER and the role of NER proteins at the 
different stages of this process. Data on the study of interaction of NER proteins, XPC-Rad23B, XPA, and RPA, with DNA intermediates of NER key stages, damage recognition and preincision complex (Fig. 1), using photoaffinity labeling are presented below.

DNA duplexes, containing photoreactive exo-N- $\{2-$ [N-(4-azido-2,5-difluoro-3-chloropyridin-6-yl)-3-aminopropionyl]-aminoethyl $\}-2$ '-deoxycytidine-5'-monophosphate (FAP-dCMP, Fig. 2, $A$ ) or 4-thiouridine (4SdUMP) in one strand, and bulky anthracene group attached to $\mathrm{dC}$ in the opposite strand, were used for the analysis of interaction of XPC-Rad23B, XPA, and RPA with DNA in case of a damage in one or both strands of the DNA duplex [13]. FAP-dCMP was shown to be recognized and processed by the bacterial and human NER systems [10, 14]. The level of cross-links to the thio-group increased while adding the bulky substitute in the opposite strand of the DNA duplex, Antr-dCMP, and also non-complementary nucleotide opposite 4SdUMP. The anthracene residue causes distortion in the structure of DNA duplex, though to a lesser degree than the FAP-group [15]. The yield of XPC modification products drastically decreased when an anthracene residue was incorporated opposite FAP-dCMP, as both strands of DNA duplex contained bulky substitutes. The experiments on binding showed that the affinity of XPC$\operatorname{Rad} 23 \mathrm{~B}$ to DNA was virtually unchanged. Therefore, the decrease in modification level is probably a consequence of geometric changes in DNA-protein complex during the introduction of bulky substituents in both strands of the DNA duplex. An analysis of the repair of DNA containing lesions in both strands in HeLa extract showed almost total inhibition of the repair process in regard to this DNA [16]. Later it was proposed that XPC interacts with the strand region opposite to the damage [17]. This assumption was directly confirmed by $\mathrm{X}$-ray structural analysis of the complex of Rad4 protein, yeast ortholog of XPC, with the damaged DNA fragment [18]. It was assumed that Rad4 binds damaged DNA by the induced fit mechanism presupposing the scanning of DNA duplex for the non-paired nucleotides, which can bind with specific domains. This assumption is in agreement with the model of multiple stage recognition in NER, according to which the damages that thermodynamically destabilize DNA duplex are the preferential NER substrates [19]. However,

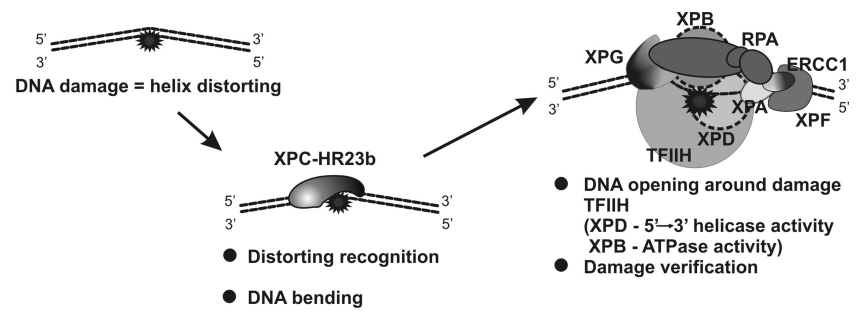

Fig. 1. Damage recognition and assembly of preincision complex in GG-NER

X-ray structural analysis of the Rad4-Rad23 complex with a DNA fragment shows only one, probably the most stable, configuration of this complex. However, the dynamic aspects of the mechanism of damage recognition by XPC-Rad23B complex in higher eukaryotes remain unclear and alternative approaches for their study, in particular the method of photoaffinity labeling, can be useful.

The use of photoreactive groups imitating bulky damage allows covalent fixing of polypeptides directly contacting this group. However, extended linkers in these structures provide an opportunity to react with the proteins located on the opposite strand of the DNA duplex. To determine the contacts of NER factors with an intact DNA strand during the process of damage recognition, there were constructed DNA structures containing 5-iodo-2'-deoxyuridine-5'-monophosphate (5I-dUMP) residues in various positions of the intact strand and dUMP fluorescein derivative (Flu-dUMP, Fig. 2, B) as a damage in the opposite strand $[20,21]$. Photoreactive groups with zero size linker, like 5I-dUMP, are supposed to react only with amino acid residues in direct contact with them [22]. The Flu-dUMP residue was used as a damage, as it was shown that this analog is recognized and repaired in the NER system [23]. The evaluation of the affinity of NER factors to DNA structures by gel-shift assay showed that none of the proteins - XPC-Rad23B, XPA, or RPA - revealed significant preference in binding damaged DNA, which is necessary for the discrimination of the damaged region in a huge massive of native DNA. These data agree with the assumption of cooperative interactions of several proteins at the stage of damage recognition. Indeed, simultaneous addition of RPA and XPC-Rad23B resulted in some increase in the affinity of the latter to different 

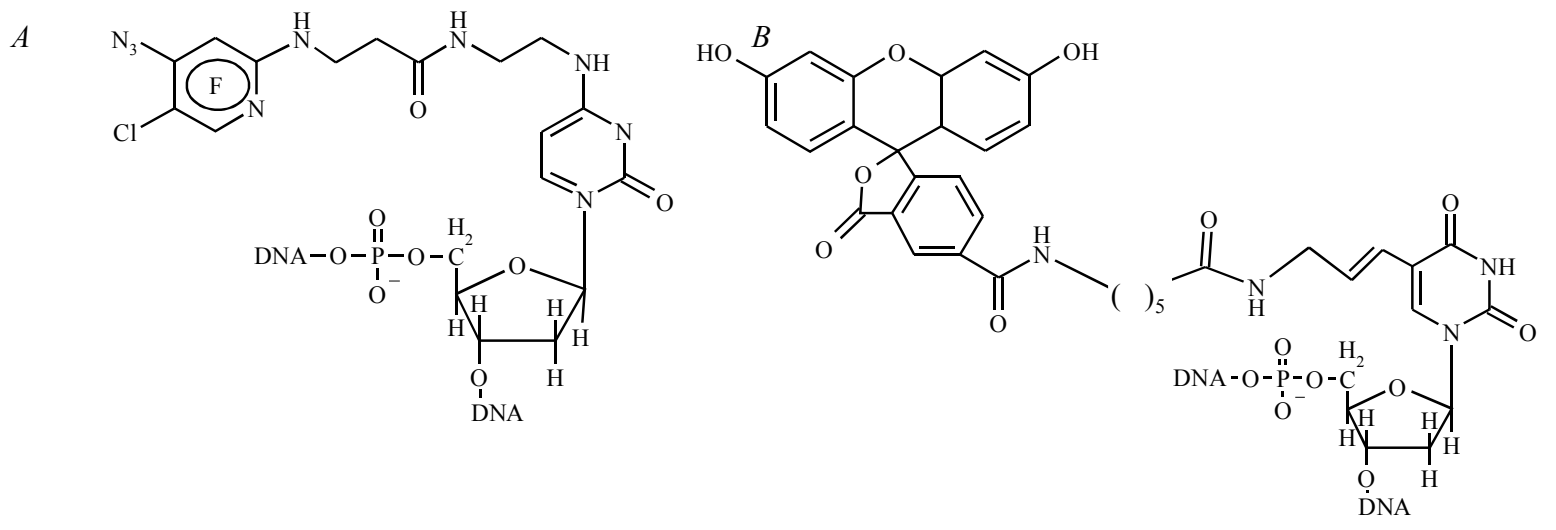

Fig. 2. Structures of bulky adducts recognized by NER system: $A-$ FAP-dCMP - exo-N- $\{2-[$ N-(4-azido-2,5-difluoro-3-chloropyridin-6-yl)-3-aminopropionyl]-aminoethyl $\}$-2'-deoxycytidine-5'-monophosphate; $B$ - Flu-dUMP - 5-\{3-[6-(carboxyamidofluoresceinyl)amidocapromoyl]allyl\}2'-deoxyuridine-5'-monophosphate

DNA structures, more remarkable in case of damaged DNA [20]. In the presence of both XPA and XPC$\operatorname{Rad} 23 \mathrm{~B}$, the effect of mutual stimulation in binding of these proteins to DNA was observed. The interaction of XPC and XPA as well as XPC and RPA during binding to UV-irradiated DNA was also shown using footprinting assay [24]. However, the mechanism of this interaction remains unclear.

RPA also stimulated modification of XPC-Rad23B by $5 \mathrm{I}$-dUMP-containing DNA structures, and the maximal stimulation was observed for DNA duplex containing non-complementary nucleotide pair near the damage [20]. The stimulation effect was shown to involve protein-protein interactions: mutant RPA lacking domains responsible for the protein-protein interactions did not affect XPC-Rad23B modification. On the addition of prokaryotic SSB protein, stimulation was not observed, evidencing to the specificity of interaction between XPC-Rad23B and RPA. Notably, the dependence of XPC-Rad23B modification intensity on the position of a 5I-dUMP residue in the intact strand corresponded with the X-ray data for Rad4, i. e. the 5I-dUMP positions demonstrating maximum levels of XPC modification coincided with the places of Rad4 and DNA contact [18]. This correspondence probably allows accounting the data on the mechanism of damage recognition obtained for the yeast protein in regard to the NER system of higher eukaryotes where proteins X-ray analysis is still missing.

XPA and RPA proteins are important elements of the complex formed on the damaged DNA at the stage preceding the damage excision by endonucleases ERCC1-
XPF and XPG, the so-called preincision complex [25]. The DNA structures containing non-complementary region of $15 \mathrm{nt}$ with bulky adduct (Flu-dUMP) in one strand may be considered as the models imitating DNA intermediates formed at the primary stage of preincision complex assembly, after partial unwinding of DNA duplex in the damaged region by TFIIH helicases [26]. The use of such structures containing 5I-dUMP in different DNA positions allowed studying XPA and RPA localization in the partly open DNA duplex. It was shown that XPA interacts basically with the transition of an open region to the duplex part [21]. This localization of XPA corresponds to its function of attracting the structure specific endonucleases to the place of damaged strand incisions [27]. Together with RPA, mainly interacting with non-damaged DNA strand, XPA participates in formation and maintaining of the proper structure of the DNA-protein complex required for precise seating and coordinate action of excision nucleases ERCC1-XPF and XPG (Fig. 2). The involvement of two RPA molecules in the preincision complex can be assumed [21]. One molecule interacts with a singlestranded region of the intact strand in partially open DNA duplex and simultaneously with XPA, and the second RPA molecule is located near the transition of the open part into the duplex, at the 3-side from the damage, and may interact with XPG. RPA might bind singlestranded DNA in this complex, being in transitional conformation [28]. The participation of more than one RPA molecules in preincision complex assembly is justified by the necessity to create contacts both with structurally different DNA regions in partly open du- 
plex and with other proteins attracted to the complex. This assumption agrees with the domain structure of RPA and its conformation, and also with the bubble size. Moreover, the seating of several RPA molecules can be necessary for further unwinding of DNA duplex to the size of open region $\sim 30 \mathrm{nt}$, preceding the excision of damaged DNA fragment $[29,30]$. It should be noted that the right orientation of XPA and RPA on DNA is achieved in the absence of TFIIH, which is probably displaced by these proteins from the complex with DNA.

In sum, the results of studying the interaction of NER proteins with model DNA structures imitating the substrates and intermediates at different stages of the process using photoaffinity labeling demonstrate the advantage of this approach in studying the architecture and dynamics of DNA-protein complex, being sensitive to local structural changes in a DNA damage region.

Acknowledgements. This work was supported by RFBR, project no. 10-04-00837, and RAS Presidium program «Molecular and Cellular Biology».

\section{Н. І. Речкунова, Я. С. Красікова, С. А. Мальцева, О. І. Лаврик}

Фотоактивні ДНК як інструмент для вивчення топографії комплексу ексцизійної репарації нуклеотидів

\section{Резюме}

Ексцизійна репарація нуклеотидів (ЕРH) - цее один з основних шляхів репарації у клітинах еукаріотів, які запобігають виникненню генетичних аномалій внаслідок пошкодження ДНК. За допомогою ЕРН відбувається видалення широкого спектра різних за структурою пошкоджень, серед яких піримідинові димери, щ⿻ формуються під дією УФ-випромінювання, та об 'ємні хімічні адукти, щчо утворюються в результаті впливу канцерогенів довкілля або хіміотерапї. Через надзвичайно високу субстратну специфичність прочесу ЕРН постає питання щчодо механізму упізнавання різних пошкоджень певним набором білків у величезному масиві непошкодженої ДНК. У представленому огляді розглядаються можливості застосування методу фотоафінної модифікації для вивчення ключових стадій ЕРН-упізнавання пошкоджень і формування передрозщеплювального комплексу.

Ключові слова: ексиизійна репарація нуклеотидів, упізнавання пошкоджень, передрозщеплювальний комплекс, фотореактивна ДНК.

\section{Н. И. Речкунова, Я. С. Красикова, Е. А. Мальцеева, О. И. Лаврик}

Фотоактивные ДНК как инструмент для исследования топографии комплекса эксцизионной репарации нуклеотидов

Резюме

Эксиизионная репарация нуклеотидов (ЭРН) - один из основных путей репарации в клетках эукариотов, предотвращающих возникновение генетических аномалий вследствие повреждения ДНК. С помощью ЭРН происходит удаление широкого спектра струк- турно различающихся повреждений, таких как пиримидиновые димеры, появляюшиеся под действием УФ-излучения, и объемные химические аддукты, образуюшиеся в результате воздействия канцерогенов окружающей среды или химиотерапии. Из-за необычайно широкой субстратнаой специфичность прочесса ЭРН возникает вопрос о механизме узнавания различных повреждений определенным набором белков в огромном массиве неповрежденной ДНК. В представленном обзоре рассматриваются возможности применения метода фотоаффинной модификации для изучения ключевых стадий ЭРН-узнавания повреждения и формирования предрасщепляющего комплекса.

Ключевые слова: эксиизионная репарачия нуклеотидов, узнавание повреждений, предрасщепляющий комплекс, фотореактивная ДНК.

\section{REFERENCES}

1. Friedberg E. C., Aguilera A., Gellert M., Hanawalt P. C., Hays J. B., Lehmann A. R., Lindahl T., Lowndes N., Sarasin A., Wood R. D. DNA repair: from molecular mechanism to human disease // DNA Repair (Amst).-2006.-5, N 8.-P. 986-996.

2. Gillet L. C., Scharer O. D. Molecular mechanisms of mammalian global genome nucleotide excision repair // Chem. Rev.2006.-106, N 2.-P. 253-276.

3. Svejstrup J. $Q$. Mechanisms of transcription-coupled DNA repair // Nat. Rev. Mol. Cell. Biol.-2002.-3, N 1.-P. 21-29.

4. Tornaletti S., Hanawalt P. C. Effect of DNA lesions on transcription elongation // Biochimie.-1999.-81, N 1-2.-P. 139-146.

5. Aboussekhra A., Biggerstaff M., Shivji M. K., Vilpo J. A., Moncollin V., Podust V. N., Protic M., Hubscher U., Egly J. M., Wood R. D. Mammalian DNA nucleotide excision repair reconstituted with purified protein components // Cell.-1995.-80, N 6.P. 859-868.

6. Araujo S. J., Tirode F., Coin F., Pospiech H., Syvaoja J. E., Stucki M., Hubscher U., Egly J. M., Wood R. D. Nucleotide excision repair of DNA with recombinant human proteins: definition of the minimal set of factors, active forms of TFIIH, and modulation by CAK // Genes Dev.-2000.-14, N 3.-P. 349-359.

7. Sugasawa K., Okamoto T., Shimizu Y., Masutani C., Iwai S., Hanaoka $F$. A multistep damage recognition mechanism for global genomic nucleotide excision repair // Genes Dev.-2001.-15, N 5.P. 507-521.

8. Naegeli H., Sugasawa K. The xeroderma pigmentosum pathway: decision tree analysis of DNA quality // DNA Repair (Amst).2011.-10, N 7.-P. 673-683.

9. Schweizer U., Hey T., Lipps G., Krauss G. Photocrosslinking locates a binding site for the large subunit of human replication protein $A$ to the damaged strand of cisplatin-modified DNA // Nucleic Acids Res.-1999.-27, N 15.-P. 3183-3189.

10. DellaVecchia M. J., Croteau D. L., Skorvaga M., Dezhurov S. V., Lavrik O. I., Van Houten B. Analyzing the handoff of DNA from UvrA to UvrB utilizing DNA-protein photoaffinity labeling // J. Biol. Chem.-2004.-279, N 43.-P. 45245-45256.

11. Khodyreva $S$. N., Lavrik $O$. I. Photoaffinity labeling technique for studying DNA replication and DNA repair // Curr. Med. Chem.-2005.-12, N 6.-P. 641-655.

12. Rechkunova N. I., Lavrik O. I. Nucleotide excision repair in higher eukaryotes: mechanism of primary damage recognition in global genome repair // Subcell. Biochem.-2010.-50.-P. 251-277.

13. Maltseva E. A., Rechkunova N. I., Petruseva I. O., Vermeulen W., Scharer O. D., Lavrik O. I. Crosslinking of nucleotide excision repair proteins with DNA containing photoreactive damages // Bioorg. Chem.-2008.-36, N 2.-P. 77-84. 
14. Maltseva E. A., Rechkunova N. I., Gillet L. C., Petruseva I. O., Scharer O. D., Lavrik O. I. Crosslinking of the NER damage recognition proteins XPC-HR23B, XPA and RPA to photoreactive probes that mimic DNA damages // Biochim. Biophys. Acta.-2007.-1770, N 5.-P. 781-789.

15. Petruseva I. O., Tikhanovich I. S., Chelobanov B. P., Lavrik O. I. RPA repair recognition of DNA containing pyrimidines bearing bulky adducts // J. Mol. Recognit.-2008.-21, N 3.-P. 154-162.

16. Buterin T., Meyer C., Giese B., Naegeli H. DNA quality control by conformational readout on the undamaged strand of the double helix // Chem. Biol.-2005.-12, N 8.-P. 913-922.

17. Maillard O., Solyom S., Naegeli H. An aromatic sensor with aversion to damaged strands confers versatility to DNA repair // PLoS Biol.-2007.-5, N 4.-e79.

18. Min J. H., Pavletich N. P. Recognition of DNA damage by the Rad4 nucleotide excision repair protein // Nature.-2007.-449, N 7162.-P. 570-575.

19. Geacintov N. E., Broyde S., Buterin T., Naegeli H., Wu M., Yan $S$., Patel D. J. Thermodynamic and structural factors in the removal of bulky DNA adducts by the nucleotide excision repair machinery // Biopolymers.-2002.-65, N 3.-P. 202-210.

20. Krasikova Y. S., Rechkunova N. I., Maltseva E. A., Petruseva I. O., Silnikov V. N., Zatsepin T. S., Oretskaya T. S., Scharer O. D., Lavrik $O$. I. Interaction of nucleotide excision repair factors XPCHR23B, XPA, and RPA with damaged DNA // Biochemistry (Mosc).-2008.-73, N 8.-P. 886-896.

21. Krasikova Y. S., Rechkunova N. I., Maltseva E. A., Petruseva I. O., Lavrik O. I. Localization of xeroderma pigmentosum group A protein and replication protein A on damaged DNA in nucleotide excision repair // Nucleic Acids Res.-2010.-38, N 22.P. 8083-8094.

22. Meisenheimer K. M., Koch T. H. Photocross-linking of nucleic acids to associated proteins // Crit. Rev. Biochem. Mol. Biol.1997.-32, N 2.-P. 101-140.

23. Nakano T., Katafuchi A., Shimizu R., Terato H., Suzuki T., Tauchi H., Makino K., Skorvaga M., Van Houten B., Ide H. Repair activity of base and nucleotide excision repair enzymes for guanine lesions induced by nitrosative stress // Nucleic Acids Res.2005.-33, N 7.-P. 2181-2191.

24. Wakasugi M., Sancar A. Order of assembly of human DNA repair excision nuclease // J. Biol. Chem.-1999.-274, N 26.P. 18759-18768.

25. Volker M., Mone M. J., Karmakar P., van Hoffen A., Schul W., Vermeulen W., Hoeijmakers J. H., van Driel R., van Zeeland A. A., Mullenders $L$. H. Sequential assembly of the nucleotide excision repair factors in vivo // Mol. Cell.-2001.-8, N 1.-P. 213-224.

26. Tapias A., Auriol J., Forget D., Enzlin J. H., Scharer O. D., Coin F., Coulombe B., Egly J. M. Ordered conformational changes in damaged DNA induced by nucleotide excision repair factors // J. Biol. Chem.-2004.-279, N 18.-P. 19074-19083.

27. Orelli B., McClendon T. B., Tsodikov O. V., Ellenberger T., Niedernhofer L. J., Scharer O. D. The XPA-binding domain of ERCC1 is required for nucleotide excision repair but not other DNA repair pathways // J. Biol. Chem.-2010.-285, N 6.P. 3705-3712.

28. Lavrik O. I., Kolpashchikov D. M., Weisshart K., Nasheuer H. P., Khodyreva S. N., Favre A. RPA subunit arrangement near the 3 '-end of the primer is modulated by the length of the template strand and cooperative protein interactions // Nucleic Acids Res.-1999.-27, N 21.-P. 4235-4240.

29. Missura M., Buterin T., Hindges R., Hubscher U., Kasparkova $J$., Brabec V., Naegeli $H$. Double-check probing of DNA bending and unwinding by XPA-RPA: an architectural function in DNA repair // EMBO J.-2001.-20, N 13.-P. 3554-3564.

30. Salas T. R., Petruseva I., Lavrik O., Bourdoncle A., Mergny J. L., Favre A., Saintome C. Human replication protein A unfolds telomeric G-quadruplexes // Nucleic Acids Res.-2006.-34, N 17.P. 4857-4865. 